\title{
Ethics of Eating in the Teaching of Al-Ghazali
}

\section{Munira Fayzulloeva*}

Department of Social Sciences, Tajik State University of La Business and Politics, Tajikistan

*Corresponding Author: Munira Fayzulloeva, Department of Social Sciences, Tajik State University of La Business and Politics, Tajikistan.
Received: February 25, 2020

Published: March 20, 2020

(C) All rights are reserved by Munira

Fayzulloeva.
Abu Muhammad Muhammad Ghazali (1059 - 1111) also expressed his views on the etiquette of decency in his ethical teachings. Because every person's behavior, including eating, also has their own etiquette.

Al-Ghazali stresses that happiness can be achieved with health, strength, longevity, science and action, excellence and perfection. It is important to eat and drink to keep your body healthy. The purpose of nutrition is to benefit from what is written in the Book of Sharif: "Eat good food and do good" (Koran, 23:51).

Al-Ghazali explains the ethics of eating as follows: Before eating, washing hands and mouth should be done to ease that tension, leaving the meal on a table or table and eating with the right, first and foremost and then others. to start a meal, not to look too much at meals, it is good to tell what to eat and to tell when eating. Slowly dropped the spit a, get another The bite is lost, it must be removed, the food must be eaten by itself, but the fruit can be taken from the other side. It is enough to eat it together and toss it two or three times, to put the mouth on the plate and to shake hands, to look at the mouths of others, to clap, to laugh, to speak with mouths and to act. bad habits and a sign of worthlessness.

The scientist reminds me that it is best not to drink water and to refrain from eating until the meal is full, as the bowl has a lot to do with food, to wash hands with a towel and to eat the front bread. rinsing your hands, mouth and teeth and nose is good for your health.

Al-Ghazali calls the stomach a "pool of lust and a source of lust", and advises that anemia should be used when the body is light and clean, enough to eat just enough to keep your stomach hungry. The present should not be satisfied, and the delicious food should not be the desire of life, not the enjoyment of food, the bread is the best food and the health of the body, if one wishes to eat it.

Al-Ghazali considers the use of alcohol as a cause of decline in nutrition and anemia, and says that gastric ulcer is the cause of all misery. The scientist explains the benefits of hunger: There are ten benefits to hunger: to cleanse the heart, to refine and to enjoy the pleasures, to make the living, to pay for science and labor; nourishment makes the person heartbroken, hard-working, over-saturated with dreams, which is too much to lose life, to eat, to wait, to prepare his tools, to take away all the necessities of life; Whosoever has little to eat, and who has the ability to heal and toilet medicine, and to eat bitter medicine; and he that is able to abound, he is able to do good and to be good [1-6].

The scientist also describes the etiquette of drinking water - it is wrong to drink the water slowly, stand or lie down. During drinking or midnight drinking it is important not to drink water that is harmful to the body, to satisfy thirst with water, and to have a great reward, but it is wrong to ask the person for chance.

Al-Ghazali insists that a person should keep his own eating habits both in private and in public, otherwise it is no different from feeding livestock.

In summary, Muhammad Ghazali's ethical ideas are of scientific and practical importance and are one of the sources of scientific knowledge. Ethical norms studied by al-Ghazali contribute to the moral and psychological development of the individual.

\section{Bibliography}

1. Koran. Trans. Arabic Krachkovskiy I.U.

2. Abu Hamid al-Ghazali. Nasihat-ul-mulk. Dushanbe: Irfon (2011).

3. Abu Hamid al-Ghazali. Research innermost secrets of the heart. Trans. Arabic A. Miniyanova. Moscow. Ansar (2006).

4. Abu Hamid al-Ghazali. Kimëi Saodat. Tashkent: Adolat (2005).

5. Abu Hamid al-Ghazali. Mukoshafat-ul-Kulub. - Trans. Arabic Miraziz Azam. -Tashkent: Adolat (2002). 
6. Abu Hamid al-Ghazali. O son. Trans. Yuldosh Eshbek. Tashkent: Movarouhhahr (2005).

Assets from publication with us

- Prompt Acknowledgement after receiving the article

- Thorough Double blinded peer review

- Rapid Publication

- Issue of Publication Certificate

- High visibility of your Published work

Website: www.actascientific.com/

Submit Article: www.actascientific.com/submission.php

Emaill us: editor@actascientific.com

Contact us: +919182824667 